\title{
PENGARUH MODEL PEMBELAJARAN TERHADAP KETERAMPILAN BERPIKIR KRITIS DAN HASIL BELAJAR PESERTA DIDIK KELAS XI MIPA SMA NEGERI 8 MANDAI (Studi Materi Pokok Larutan Penyangga)
}

\author{
Faisal, Tabrani Gani ${ }^{1}$, Muhammad Danial ${ }^{2}$ \\ 1,2 Dosen Pascasarjana Pendidikan Kimia Universitas Negeri Makassar \\ Email: faisal.chemistryunm2010@gmail.com
}

\begin{abstract}
ABSTRAK
Penelitian ini adalah penelitian eksperimen semu yang bertujuan untuk mengetahui pengaruh model pembelajaran terhadap keterampilan berpikir kritis dan hasil belajar peserta didik kelas XI MIPA SMA Negeri 8 Mandai materi pokok larutan penyangga. Desain penelitian Pretest treatment Postest Design. Populasi dalam penelitian ini adalah seluruh peserta didik kelas XI MIPA SMA Negeri 8 Mandai tahun pelajaran 2017/2018 yang berjumlah 4 kelas. Penentuan sampel dilakukan secara random kelas dan terpilih kelas XI MIPA 1 sebagai kelas yang dibelajarkan model pembelajaran discovery learning dan kelas XI MIPA 2 sebagai kelas yang dibelajarkan dengan model pembelajaran langsung. Data dianalisis menggunakan analisis deskriptif dan uji independent sample T-Test. Hasil analisis deskriptif diperoleh data rata-rata nilai $N$-gain keterampilan berpikir kritis pada kelompok model pembelajaran discovery learning sebesar 0,67 dengan kategori sedang dan kelompok model pembelajaran langsung sebesar 0.55 dengan kategori sedang. Nilai $\mathrm{N}$-gain hasil belajar pada kelompok model pembelajaran discovery learning sebesar 0,76 dengan kategori tinggi dan kelompok model pembelajaran langsung sebesar 0.66 dengan kategori sedang. Hasil pengujian hipotesis menunjukkan terdapat pengaruh model pembelajaran terhadap keterampilan berpikir kritis dan hasil belajar kelas XI MIPA SMA Negeri 8 Mandai pada materi pokok larutan penyangga.
\end{abstract}

Kata kunci: Model pembelajaran, keterampilan berpikir kritis, hasil belajar, dan larutan penyangga.

\begin{abstract}
The research is quasi experiment research which aims to discover the effect of learning models toward critical thinking skill and learning outcomes students of class XI MIPA SMAN 8 Mandai study on buffer solution. The research uses pretest treatment posttest design. Population of the research was all students in class XI MIPA SMAN 8 Mandai school year 2017/2018 which amounted to 4 class. Determination of the sample is done randomly and class XI MIPA 1 has been choose as the class taught use the discovery learning model and class XI MIPA 2 as the class taught use the direct learning model. The data has been analyzed by using descriptive analysis and using T-Test for the sample independent test. The results of these analyzes has obtained the average outcome of the $\mathrm{N}$-gain value of the critical thinking skill on the discovery learning model grup is 0.67 in medium category, and the direct learning model grup is 0.55 in medium category. The $\mathrm{N}$-gain value student achievement on the discovery learning model grup is 0.76 for the hight category and the direct leaning model grup is 0.66 in medium category. The result of a hypothesis test suggests the effect of learning models toward critical thinking skill and learning outcomes students of class XI MIPA SMAN 8 Mandai study on buffer solution.
\end{abstract}

Keywords : Learning models, critical thinking skill, learning outcomes and buffer solution 


\section{PENDAHULUAN}

Kurikulum saat ini menganut pandangan bahwa suatu pengetahuan tidak dipindahkan begitu saja dari seorang guru kepada peserta didiknya, melainkan peserta didik sebagai objek belajar harus memiliki kemampuan aktif untuk mencari, menemukan, mengolah dan menggunakan pengetahuan. Keaktifan peserta didik dinilai dari peranannya dalam pembelajaran, seperti bertanya, menjawab pertanyaan dan memberi tanggapan. Hal ini yang menyebabkan seorang pendidik harus memberi kesempatan kepada peserta didiknya untuk menemukan dan menyusun sendiri pengetahuan dalam proses kognitifnya. Pendekatan dan model pembelajaran yang ada dalam kurikulum 2013 menginginkan agar peserta didik mampu belajar secara mandiri serta proses pembelajaran tidak lagi berpusat pada guru (teacher centered) melainkan berpusat pada peserta didik (student centered).

Keterampilan berpikir kritis merupakan sebuah kemampuan yang dimiliki setiap orang untuk menganalisis ide atau sebuah gagasan ke arah yang lebih spesifik untuk mengejar pengetahuan yang relevan dengan melibatkan evaluasi bukti. Keterampilan berpikir kritis sangat diperlukan untuk menganalisis suatu permasalahan sampai pada tahap pencarian solusi sehingga mereka sudah terlatih menyelesaikan berbagai persoalan yang dihadapi, termasuk melihat sejauh mana kemampuan yang dimilikinya. Berpikir kritis sering muncul setelah seseorang menemui suatu masalah. Menurut para ahli yang kemudian diungkapkan kembali oleh Rahardjo (2010) bahwa berpikir kritis dapat dilatih, dan cara melatihnya dapat dilakukan dengan cara mempertanyakan apa yang dilihat dan didengar, setelah itu dilanjutkan dengan bertanya mengapa dan bagaimana tentang hal tersebut. Dengan demikian, semua orang memiliki kesempatan yang sama dalam meningkatkan keterampilan berpikir kritis, hal tersebut disebabkan pada dasarnya setiap manusia memiliki potensi dasar untuk berpikir, tinggal bagaimana cara dan usaha mereka mengoptimalkan potensi tersebut.

Salah satu model pembelajaran yang dapat meningkatkan keterampilan berpikir kritis adalah model discovery learning. Model pembelajaran discovery learning atau pembelajaran penemuan merupakan suatu rangkaian kegiatan belajar yang melibatkan secara maksimal seluruh kamampuan peserta didik untuk mencari dan menyelidiki secara sistematis, kritis, logis, analitis sehingga peserta didik dapat merumuskan sendiri penemuannya. Pengetahuan yang diperoleh dengan belajar penemuan menunjukkan beberapa kebaikan, yaitu pengetahuan yang diperoleh akan bertahan lama dan lebih mudah diingat. Model tersebut dianggap mampu mengaktifkan peserta didik, sehingga peserta didik lebih banyak terlibat dalam pembelajaran daripada guru. Sebagaimana yang diketahui bahwa belajar aktif merupakan hal yang sangat dibutuhkan oleh peserta didik untuk mendapatkan hasil yang maksimum dalam pembelajaran.

Model pembelajaran langsung merupakan model pembelajaran yang mengacu pada guru yang terlibat aktif dalam menyajikan isi pelajaran kepada seluruh peserta didik di kelas. Peranan guru selama proses pembelajaran sangatlah dominan, guru menjadi sumber belajar yang sangatlah penting. Sehingga peranan peserta didik dalam proses pembelajaran sangatlah kurang, peserta didik langsung menerima apa yang guru sampaikan. Model pembelajaran langsung cenderung membuat peserta didik kurang terlibat aktif dalam menemukan konsep pembelajaran. Peserta didik kurang terlibat langsung dalam proses pembelajaran, sehingga peserta didik tidak terlatih untuk berpikir kritis, dengan demikian hasil belajar yang diperoleh peserta didik rendah. 
Materi larutan penyangga dalam pembelajaran kimia, merupakan materi yang banyak mengandung konsep-konsep yang sangat perlu dikuasai oleh peserta didik, menurut pemahaman, keterampilan, dan latihan sehingga jika tidak menguasai konsep yang terdapat di dalam materi, maka peserta didik tidak akan dapat membangun pengetahuan, akibatnya mereka akan mengalami kesulitan dalam proses pembelajaran. Selain itu, larutan penyangga juga merupakan materi kimia yang erat kaitannya dengan kehidupan sehari-hari, sehingga dalam memahami materi larutan penyangga, peserta didik tidak hanya menghafal teorinya saja, tetapi perlu mengaitkan materi larutan penyangga dengan contoh dalam kehidupan. Pembelajaran yang menghubungkan suatu konsep dengan contoh dalam kehidupan akan lebih bertahan lama dalam memori seseorang.

Sekolah SMA Negeri 8 Mandai merupakan salah satu sekolah di Kabupaten Maros yang telah menerapkan kurikulum 2013. Pada kurikulum 2013, pembelajaran berorientasi pada peserta didik. Bagaimana peserta didiknya harus mengembangkan potensi yang dimiliki untuk menemukan sendiri konsep yang diberikan oleh guru. Guru sendiri belum terlalu menerapkan suatu model pembelajaran yang tepat untuk memfasilitasi peserta didik dalam mengembangkan keterampilan berpikir kritis. Sehingga hasil belajar yang diperoleh masih relatif rendah.

Berdasarkan hasil observasi yang dilakukan pada peserta didik kelas XI MIPA SMA Negeri 8 Mandai melalui guru mata pelajaran kimia pada bulan Januari 2018, bahwa nilai kimia pada materi larutan penyangga lebih rendah dibandingkan materi lainnya. Persentase ketuntasan yang dapat dicapai peserta didik adalah $50 \%$ dari kriteria ketuntasan minimal 75. Hal ini menunjukkan bahwa sebagian besar peserta didik kurang memahami materi kimia tersebut. Hasil belajar yang rendah diperoleh peserta didik diduga disebabkan karena keterampilan berpikir kritis peserta didik masih rendah. Hasil wawancara terhadap beberapa peserta didik diperoleh gambaran bahwa peserta didik menganggap pelajaran kimia sebagai pelajaran yang sulit. Peserta didik hanya berusaha untuk menghafal rumusrumus dan pengertian tertentu untuk mengerjakan soal hitungan tanpa memahami makna dari pembelajaran tersebut, sehingga berdampak pada rendahnya daya ingat peserta didik. Selain itu, pada aktivitas pembelajaran yang dilaksanakan, peranan guru sangat dominan. Sehingga peserta didik tidak terlibat secara langsung dalam proses pembelajaran, peserta didik tidak memiliki banyak ruang untuk aktif dalam proses pembelajaran. Selain itu, pada soal-soal evaluasi yang diberikan oleh guru, soalsoal tersebut mayoritas merupakan soal yang serupa yang telah diberikan pada saat proses pembelajaran berlangsung sehingga peserta didik lebih banyak dituntut untuk mengembangkan proses mengingatnya. Mengingat konsep ini sangatlah penting, maka diperlukan cara penyajian pembelajaran yang lebih baik untuk memotivasi dan memfasilitasi peserta didik dalam mengembangkan keterampilan berpikir kritis, guna meningkatkan hasil belajarnya. Bertolok dari masalah tersebut, diperlukan suatu alternatif pembelajaran seperti model pembelajaran discovery learning yang akan dapat mendorong peserta didik untuk lebih aktif dalam pembelajaran.

\section{METODE PENELITIAN}

Penelitian ini merupakan bagian dari penelitian induk Penelitian Strategi Nasional Institusi (PSNI) 2018 yang diketuai oleh Prof. Dr. Muhammad Danial, M.Si. yang merupakan jenis penelitian pengembangan yang mengkaji pengembangan perangkat pembelajaran kimia SMA berbasis investigasi (dengan model Discovery Learning) dan pengaruhnya terhadap keterampilan berpikir kritis, metakognisi, dan 
penguasaan konsep larutan penyangga oleh peserta didik. Namun dalam rangka penyusunan tesis ini juga dilakukan kajian mengenai pengaruh model pembelajaran terhadap keterampilan berpikir kritis dan hasil belajar yang merupakan kajian perbedaan. Jenis penelitian ini adalah eksperimen semu (quasi eksperimental design) yang bertujuan untuk mengetahui pengaruh model pembelajaran discovery learning dan model pembelajaran langsung terhadap keterampilan berpikir kritis dan hasil belajar. Eksperimen semu tidak dapat mengontrol keseluruhan variabel-variabel yang berpengaruh karena itu sebelum dilakukan perlakuan, kedua kelas diberikan pretest untuk mengetahui sejauh mana kemampuan dasar peserta didik pada materi larutan penyangga. Kemudian keduanya diberikan perlakuan yang berbeda. Setelah itu diberikan postest untuk mengetahui sejauh mana pengetahuan peserta didik terhadap konsep larutan penyangga setelah pembelajaran.

Desain yang digunakan dalam penelitian ini yaitu pretes treatment postest design yang disajikan dalam Tabel.1. Penelitian ini dilaksanakan pada semester genap tahun ajaran 20172018 di SMA Negeri 8 Mandai.

Tabel 1. Desain Penelitian

\begin{tabular}{|l|l|l|l|}
\hline $\mathrm{A}$ & $O_{1}$ & $X_{1}$ & $O_{2}$ \\
\hline $\mathrm{B}$ & $O_{3}$ & $X_{2}$ & $O_{4}$ \\
\hline
\end{tabular}

Keterangan:

A : Model Pembelajaran Discovery Learning

B : Model Pembelajaran Langsung

$\mathrm{X}_{1}$ : Perlakuan yang diberikan pada kelas A berupa penerapan Model Pembelajaran Discovery Learning

$\mathrm{X}_{2}$ : Perlakuaan yang diberikan pada kelas B berupa penerapan Model Pembelajaran Langsung

$\mathrm{O}_{1}$ : Keterampilan Berpikir Kritis dan
Hasil belajar peserta didik sebelum penerapan Model Pembelajaran Discovery Learning

$\mathrm{O}_{2}$ : Keterampilan Berpikir Kritis dan Hasil belajar peserta didik sesudah penerapan model pembelajaran Discovery Learning

$\mathrm{O}_{3}$ : Keterampilan Berpikir Kritis dan Hasil belajar peserta didik sebelum penerapan model pembelajaran langsung

$\mathrm{O}_{4}$ : Keterampilan Berpikir Kritis dan Hasil belajar peserta didik sesudah penerapan model pembelajaran langsung

Variabel dalam penelitian ini terdiri dari dua variabel, yaitu variabel independen (variabel bebas) dan variabel dependen (variabel terikat). Variabel bebas (X) adalah model pembelajaran yang terdiri dari dua varian, yaitu model pembelajaran discovery learning dan model pembelajaran langsung dan variabel terikatnya (Y) adalah kemampuan berpikir kritis dan hasil belajar kimia.

Populasi dalam penelitian ini adalah semua kelas XI MIPA SMA Negeri 8 Mandai tahun pelajaran 2017/2018 terdiri dari empat kelas dengan jumlah 120 peserta didik. Sampel penelitian ini dilakukan dengan cara random sampling. Kelas XI IPA 1 sebagai kelas A dan kelas $\mathrm{XI}_{\mathrm{IPA}}$ sebagai kelas $\mathrm{B}$. Instrument dalam penelitian ini adalah tes tertulis berupa essay digunakan untuk mengukur keterampilan berpikir kritis dan hasil belajar.

Teknik analisis data menggunakan analisis deskriptif dan inferensial. Untuk mengetahui adanya peningkatan keterampilan berpikir kritis dan hasil belajar peserta didik antara kelas A dan kelas B digunakan analisis normalized gain (N-gain). Menurut Hake (1999) dapat digunakan rumus:

$$
<g\rangle=\frac{\text { skor postes }- \text { skor pretest }}{\text { skor maksimal-skor pretes }}
$$


Tabel 2. Kriteria nilai gain score ternormalisasi

\begin{tabular}{cc}
\hline Nilai $\langle g\rangle$ & Kriteria \\
$\langle g\rangle \geq 0,7$ & Tinggi \\
$0,7\langle g\rangle \geq 0,3$ & Sedang \\
$\langle g\rangle\langle 0,3$ & Rendah \\
\hline
\end{tabular}

(Hake : 1999)

Data yang diperoleh kemudian dianalisis dengan uji Independent Sample T-Test, terlebih dahulu diuji dengan uji normalitas dan uji homogenitas. Uji hipotesis digunakan untuk mengetahui pengaruh model pembelajaran terhadap keterampilan berpikir kritis dan hasil belajar peserta didik kelas XI MIPA SMA Negeri 8 Mandai.

Uji hipotesis berpedoman berdasarkan nilai signifikansi:

(1) Jika nilai signifikansi > 0,05, maka $\mathrm{H}_{0}$ diterima;

(2) Jika nilai signifikansi $<0,05$, maka $\mathrm{H}_{0}$ ditolak.

\section{HASIL DAN PEMBAHASAN}

\section{Deskripsi Keterampilan Berpikir Kritis}

Dari penelitian yang telah dilakukan pada kedua kelas yaitu kelas A (XI MIPA 1) dan kelas B (XI MIPA 2) diperoleh data tentang keterampilan berpikir kritis peserta didik berdasarkan kategori dan nilai rata-rata $\mathrm{N}$-gain pada tiap indikator, dapat dilihat pada Tabel 3.

Tabel 3.Kategori keterampilan berpikir kritis peserta didik kelas A dan kelas B

\begin{tabular}{cccccc}
\hline \multirow{2}{*}{ Kategori } & \begin{tabular}{c} 
Prese \\
ntase \\
\cline { 3 - 6 }
\end{tabular} & \multicolumn{2}{c}{ Kelas A } & \multicolumn{2}{c}{ Kelas B } \\
\cline { 3 - 6 } & $\begin{array}{c}\text { Frek } \\
\text { uensi }\end{array}$ & $\begin{array}{c}\text { Persen } \\
\text { tase } \\
(\boldsymbol{\%})\end{array}$ & $\begin{array}{c}\text { Freku } \\
\text { ensi }\end{array}$ & $\begin{array}{c}\text { Persen } \\
\text { tase } \\
(\boldsymbol{\%})\end{array}$ \\
\hline Tinggi & $>80$ & 7 & 23,33 & 4 & 13,33 \\
\hline Sedang & $60-80$ & 18 & 60 & 13 & 43,33 \\
\hline Rendah & $<60$ & 5 & 16,67 & 13 & 43,33 \\
\hline \multicolumn{2}{c}{ Jumlah } & 30 & 100 & 30 & 100 \\
\hline
\end{tabular}

(Sumber: Lampiran 9 Nilai Hasil Belajar Peserta Didik)

Hasil dan analisis data menunjukkan bahwa nilai rata-rata peserta didik pada kelas A yang dibelajarkan dengan model pembelajaran discovery learning lebih tinggi daripada kelas B yang dibelajarkan dengan model pembelajaran langsung. Hal ini dikarenakan peserta didik terlibat secara aktif

untuk mencari dan menemukan sendiri konsep pembelajaran sehingga akan tersimpan lebih lama dan sulit dilupakan (Hosnan, 2014).

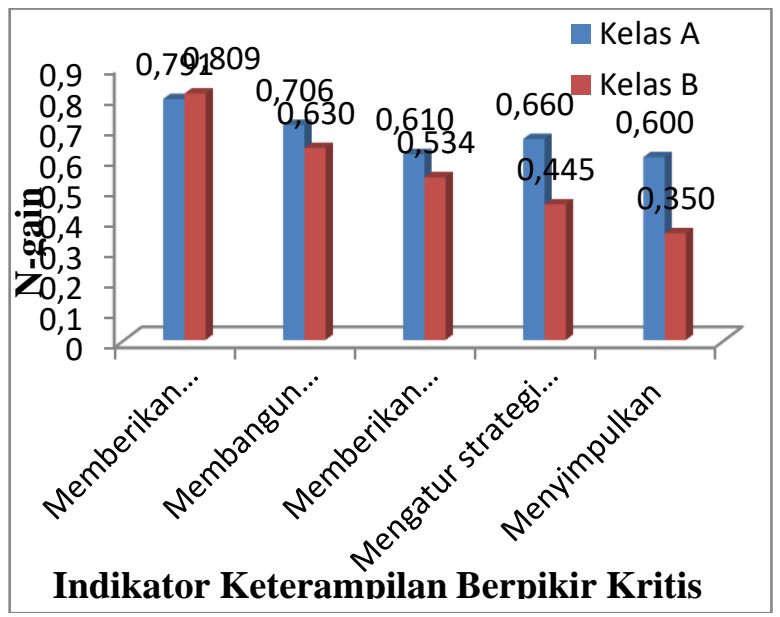

Gambar 1. Rata-rata $N$-gain tiap indikator keterampilan berpikir kritis kelas A dan kelas B

Berdasarkan Gambar 1, diketahui bahwa terjadi peningkatan ratarata $N$-gain pada tiap indikator keterampilan berpikir kritis yang diujikan peningkatan yang signifikan terdapat pada indikator memberikan penjelasan sederhana dengan kategori tinggi. Hal ini disebabkan karena sebagian peserta didik mampu menuliskan data yang dimaksudkan dari pertanyaan yang disajikan seperti menjelaskan dan menuliskan informasi yang diketahui dari permasalahan yang diberikan dalam suatu soal. Hal ini sangat mempengaruhi keterampilan berpikir kritis. Selain itu, peserta didik aktif dalam mencari informasi dari berbagai sumber belajar baik dari buku-buku maupun internet sehingga memudahkan mereka dalam menjawab soal.

Indikator membangun keterampilan dasar, memberi penjelasan lebih lanjut, 
mengatur strategi dan taktik dan menyimpulkan berada pada ketegori sedang. Indikator menyimpulkan meskipun mengalami peningkatan namun nilai ratarata yang diperoleh masih rendah dibandingkan indikator lainnya. Disebabkan karena peserta didik tidak menuliskan kesimpulannya walaupun jawabannya benar, dan kalaupun menjawab semua namun hasil perhitungannya salah sehingga pada saat menyimpulkan menjadi salah pula, pada instrument penelitian terdiri dari sebagian besar soal perhitungan dimana pengajaran yang dilaksanakan lebih mengarah kepada konsep-konsep.

Perbandingan kriteria berpikir kritis dengan kategori tinggi, sedang dan rendah antara kelas A dan kelas B menunjukkan bahwa pada kelas A lebih baik daripada kelas B.

\section{Deskripsi Hasil Belajar}

Berdasarkan hasil belajar peserta didik kelas A (XI IPA 1) yang dibelajarkan dengan model discovery learning dan kelas B (XI IPA 2) yang dibelajarkan dengan model pembelajaran langsung diperoleh hasil analisis deskriptif yang menunjukkan hasil belajar kognitif peserta didik pada materi larutan penyangga dapat dilihat pada Tabel 4 dan nilai $\mathrm{N}$-gain hasil belajar peserta didik pada Tabel 5.

Tabel 4. Nilai deskriptif keterampilan berpikir kritis peserta didik kelas A dan kelas B

\begin{tabular}{ccc}
\hline \multirow{2}{*}{ Statistik Deskriptif } & \multicolumn{2}{c}{ Nilai Statistik } \\
\cline { 2 - 3 } & Kelas A & Kelas B \\
\hline Jumlah Sampel $(n)$ & 30 & 30 \\
\hline Nilai Tertinggi & 90 & 85 \\
\hline Nilai Terendah & 50 & 45 \\
\hline Rata-Rata & 71,33 & 64,32 \\
\hline Standar Deviasi & 11,67 & 12,21 \\
\hline
\end{tabular}

(Sumber : Lampiran 8 Nilai Keterampilan Berpikir Kritis)

Tabel 5. Data $N$-gain peserta didik kelas A dan kelas B

\begin{tabular}{llll}
\hline No & Kelas & N-Gain & Kategori \\
\hline
\end{tabular}

\begin{tabular}{lccc}
\hline 1. & A & 0.761 & Tinggi \\
\hline 2. & B & 0.662 & Sedang \\
\hline \multicolumn{4}{c}{ (Sumber: Lampiran } \\
9 & Nilai Hasil Belajar & Peserta Didik) \\
& Hasil & pengujian & hipotesis
\end{tabular}

menunjukkan bahwa nilai $t_{\text {hitung }}>t_{\text {tabel }}$ dan nilai signifikan (2-tailed) adalah (2,58> $0,05)$ dan $(0,010<0,05)$ dengan nilai $\alpha=$ 0,05 diketahui bahwa signifikansi (sig.) < $\alpha$. Artinya, $\mathrm{H}_{0}$ ditolak dan $\mathrm{H}_{1}$ diterima, sehingga dari hasil uji $t$ tersebut disimpulkan bahwa terdapat pengaruh model pembelajaran terhadap keterampilan berpikir kritis peserta didik kelas XI MIPA SMA Negeri 8 Mandai.

Setelah dilakukan uji normalitas dan uji homegenitas, diperoleh data dari kedua kelas terdistribusi normal dan memiliki varians yang homogen sehingga dapat dilakukan pengujian hipotesis pada Tabel 6.

Tabel 6. Hasil Uji t

\begin{tabular}{c|cccc}
\hline & Kelas & $\mathrm{t}$ & $\mathrm{df}$ & $\begin{array}{c}\text { Sig. (2- } \\
\text { tailed) }\end{array}$ \\
\hline $\mathrm{N}-$ & Kelas A & 2.653 & 58 & .010 \\
\cline { 2 - 5 } gain & Kelas B & 2.653 & 57.960 & .010 \\
\hline
\end{tabular}

Berdasarkan Tabel 6. terlihat bahwa nilai thitung $>t_{\text {Tabel }}$ dan nilai signifikansi diperoleh sebesar 0,010, maka disimpulkan $\mathrm{H}_{0}$ ditolak dan $\mathrm{H}_{1}$ diterima pada taraf signifikansi 0,05 . Hal ini menunjukkan bahwa model pembelajaran berpengaruh terhadap keterampilan berpikir kritis dan hasil belajar kelas XI MIPA SMA Negeri 8 Mandai

Data hasil penelitian dan analisis data diperoleh bahwa peserta didik yang dibelajarkan dengan model discovery learning memiliki hasil belajar kimia yang lebih baik daripada peserta didik yang dibelajarkan dengan model pembelajaran langsung. Artinya, model discovery learning memberikan pengaruh terhadap hasil belajar peserta didik. Hal ini dibuktikan dengan rata-rata $N$-gain hasil belajar peserta didik pada kelas A sebesar 0,761 dengan kategori tinggi sedangkan kelas B sebesar 0,662 dengan kategori sedang. Peningkatan hasil belajar dengan menggunakan model discovery learning 
menghadapkan peserta didik kepada pengalaman kongkrit sehingga peserta didik belajar secara aktif, dimana mereka didorong untuk mengambil inisiatif dalam usaha memecahkan masalah, dan mengambil keputusan.

\section{SIMPULAN DAN SARAN}

Berdasarkan hasil dan pembahasan yang telah dibahas dapat disimpulkan bahwa

1. Terdapat pengaruh model pembelajaran terhadap keterampilan berpikir kritis peserta didik Kelas XI MIPA SMA Negeri 8 Mandai pada materi pokok larutan penyangga dengan nilai $n$-gain kelas yang dibelajarkan model discovery learning sebesar 0,67 dengan kategori sedang dan kelas yang dibelajarkan model pembelajaran langsung sebesar 0,55 dengan kategori sedang.

2. Terdapat pengaruh model pembelajaran terhadap hasil belajar peserta didik Kelas XI MIPA SMA Negeri 8 Mandai pada materi pokok larutan penyangga dengan nilai $n$-gain kelas yang dibelajarkan model discovery learning sebesar 0,76 dengan kategori tinggi dan kelas yang dibelajarkan model pembelajaran langsung sebesar 0,66 dengan kategori sedang.

Adapun saran:

1. Bagi pendidik, penggunaan model discovery learning dapat dijadikan salah satu alternatif model pembelajaran di kelas untuk meningkatkan keterampilan berpikir kritis dan hasil belajar.

2. Keterampilan berpikir kritis adalah salah satu aspek penting yang dapat dijadikan sebagai acuan berpikir untuk memecahkan masalah-masalah yang dihadapi peserta didik dalam proses pembelajaran.

3. Bagi peneliti selanjutnya, dapat menjadi informasi oleh peneliti lain untuk diterapkan atau dikembangkan dengan penelitian berikutnya yang sejenis pada materi yang berbeda.

\section{DAFTAR RUJUKAN}

Abidin, Yunus. 2014. Desain Sistem Pembelajaran Dalam Konteks Kurikulum 2013. Bandung: Refika Aditama.

Annafi, N. 2016. Pengaruh Penerapan LKPD Berbasis Inkuiri Terbimbing di MAN 1 Kota Bima. Journal of EST, Volume 2 Nomor 2 Agustus hal. 98-104. P-ISSN : 2460-1497, e- ISSN: 2477-3840. Diakses: Online 24 Januari 2018.

Anni. 2004. Psikologi Belajar. Semarang: UPT MKK UNNES.

Arends, Richard L. 2008. Learning to Teach. New York: Mc Graw-Hill Companies.

Aslan, D., Lia Auliandari. 2017. Pengaruh Model Pembelajaran Discovery Learning Terhadap Hasil Belajar Siswa Materi Ekologi Berbantu Data Penelitian Iklim Mikro Ruang Terbuka Hijau Berdasarkan Habitus Vegetasi. Prosiding Seminar Nasional Pendidikan Volume 2 No.1 Th. Jan-Des. 2017.

Chang, Raymond. 2005. Kimia Dasar: Konsep-Konsep Inti (Jilid 2/ Edisi Ketiga). Jakarta: Erlangga.

Chebii, R., W. Samwuel, dan K. Joel. 2012. Effects of Science Process Skills Mastery Learning Approach on Students Acquisition of Selected Chemistry Practical Skills in School. Scientific Research, 3(8):1291-1296.

Costa, L Arthur. 1985. Developing Minds A Resource Book For Teachning Thingking. Printed in the United States Of America.ASCD.

Danial, M., Gani, T., Husnaeni. 2017. Pengaruh Model Pembelajaran dan Kemampuan Awal Terhadap Kemampuan Berpikir Kritis dan Pemahaman Konsep Peserta Didik. Journal of Educational Science and 
Technology. Volume 3 Nomor 1 April 2017 Hal. 18-32.

Ennis, R.H. 2002. An Outline of Goals for a Critical ThinkinG Curriculum and Its Assessment. This is a revised version of a presentation at the Sixth International Conference on Thinking at MIT, Cambridge, MA, July, 1994. http://www.criticalthinking.net/goal s.html. Diakses pada 12 Januari 2018.

Ennis, R.H. 1996. Critical Thinking. New Jersey: Prentice Hall Inc.

Gultom, Silitonga. 2010. Kompetensi Guru. Medan: Unimed.

Hamalik. 2003. Proses Belajar Mengajar. Bandung: Bumi Aksara.

Hamdani. 2011. Strategi Belajar Mengajar. Bandung: Pustaka Setia.

Haris. 2009. Evaluasi Pembelajaran. Yokyakarta: Multi Pressindo.

Hosnan, M. 2014. Pendekatan Saintifik dan Konseptual dalam Pembelajaran Abad 21. Bogor: Ghalia Indonesia.

Hudoyo, Herman. 1980. Teori Dasar Belajar-Mengajar Matematika. Jakarta: Proyek Pengembangan Pendidikan Guru (P3G) Departemen Pendidikan dan Kebudayaan.

Masrida, Yusminah, Mushawwir. 2016. Pengaruh Model Pembelajaran Discovery Terhadap Keterampilan Berpikir Kritis dan Hasil Belajar IPA Kelas VIII MTSN Libureng Kabupaten Bone. Jurnal Bionature. Volume 17 Nomor 2 81-87.

Muharram dan Jusniar. 2012. Meningkatkan Partisipasi Siswa Kelas $\mathrm{X}_{1}$ SMAN 3 Sungguminasa Melalui Penerapan Pembelajaran Penemuan Terbimbing pada Materi Pokok Senyawa Hidrokarbon. Jurnal Chemica Vol.13 Nomor I, 68-76.

Muijs, Daniel; Renolds, David. 2008. Effective Teaching: Teori dan Aplikasi. Penerjemah: Soetjipto,
Helly Prajitno; Soetjipto, Sri Mulyantini. Yogyakarta : Pustaka Pelajar.

Nur, M. 2000. Pengajaran Berpusat kepada siswa dan Pendekatan Konstruktivis dalam Pengajaran. Surabaya: PSMS Program Pascasarjana Unesa.

Purba, Michael. 2007. Kimia untuk SMA Kelas XI. Jakarta : Penerbit Erlangga.

Purwanto. 1990. Psikologi Pendidikan. Bandung: PT Remaja Rosdakarya.

Rahardjo, M., 2010. Pemikiran Kebijakan Pendidikan Kontemporer. Malang : UIN Maliki Press.

Rusyna, A. 2014. Keterampilan Berpikir. Yogyakarta: Ombak.

Sagala, Syaiful. 2009. Konsep dan Makna Pembelajaran.Bandung: Alfabeta.

Sanjaya, W. 2012. Pembelajaran dalam Implementasi Kurikulum Berbasis Kompetensi. Jakarta: Kencana Prenada Media Group.

Sanjaya, W. 2012. Strategi Pembelajaran Berorientasi Standar Proses Pendidikan. Jakarta: Kencana Prenada Media Group.

Sardiman. 1992. Ilmu Pendidikan. Bandung : Penerbit PT. Bina Aksara.

Serungke, M. 2017. Pengaruh Model Pembelajaran Guided Discovery Terhadap Hasil Belajar dan Keterampilan Berpikir Kritis Siswa. Prosiding Seminar Nasional MIPA III. Program Studi Magister Pendidikan IPA PPs Unsyiah Aceh.

Slameto, 2003. Belajar dan Faktor-faktor yang mempengaruhinya. Jakarta: Rineka Cipta.

Slavin, Robert E. 2008. Psikologi Pendidikan: Teori dan Praktik (Edisi Kedelapan, Jilid 1). Jakarta: Indeks.

Soeparman, Alwi. 2001. Desain Instruksional. Jakarta: PAU dan DIKTI DIKBUD

Sudjana, Nana. 1996. Cara Belajar Siswa Aktif Dalam Proses Belajar 
Mengajar, Bandung : Sinar Baru

Algensindo.

Sudjana, Nana. 2004. Dasar-dasar Proses Belajar Mengajar. Bandung : Sinar Baru Algensindo.

Sudjana, Nana. 2010. Penilaian Hasil Proses Belajar Mengajar. Bandung : PT Remaja Rosdakarya.

Sugiyono. 2010. Metode Penelitian Pendidikan Pendekatan Kuantitatif, Kualitatif dan $R \& D$. Bandung : Alfabeta.

Suprijono, Agus. 2010. Cooperative Learning Teori \& Aplikasi Paikem. Surabaya : Pustaka Belajar.

Susanti, E., Jamhari, M., Syamsurizal. 2016. Pengaruh Model Pembelajaran Discovery Learning Terhadap Keterampilan Sains dan Hasil Belajar Siswa Kelas VIII Tentang IPA SMP Advent Palu. Jurnal Sains dan Teknologi Taduloko, Volume 5 Nomor 3, Agustus 2016 hlm 36-41.

Syah, M. (2004). Psikologi Pendidikan dengan Pendekatan Baru. Bandung : PT Remaja Rosdakarya.

Trianto, 2012. Mendesain Model Pembelajaran Inovatif-Progresif. Jakarta: Kencana.

Trianto. 2007. Model-Model Pembelajaran Inovatif Berorientasi Konstruktivistik: Konsep, Landasan Teoritis-Praktis dan Implementasinya.

Yogyakarta: Pustaka Pelajar.

Yusnia, Sugeng, dan Dwiyono. 2017. Pengaruh Model Pembelajaran Discovery Learning Terhadap Kemampuan Berpikir Kritis Mahasiswa. Jurnal Pendidikan. Volume 2 Nomor 10 1308-1314. Diakses: Online 20 Mei 2018.

Zamroni dan Mahfudz. 2009. Panduan Teknis Pembelajaran yang Mengembangkan Critical Thinking. Jakarta: Kementerian Pendidikan Nasional Direktorat Pengembangan SMA. 